\title{
CRIOULIZAÇÃO EM CABO VERDE E SÃO TOMÉ E PRÍNCIPE: DIVERGÊNCIAS HISTÓRICAS E IDENTITÁRIAS
}

Gerhard Seibert*

$\mathrm{A}$ s primeiras sociedades crioulas do mundo atlântico emergiram ao longo do século XVI em Cabo Verde e em São Tomé e Príncipe. Quando os portugueses chegaram pela primeira vez aos dois arquipélagos africanos, por volta de 1460 e 1470, respetivamente, ambos encontravam-se desabitados. Pouco depois da descoberta, os portugueses povoaram as ilhas de Santiago e do Fogo, em Cabo Verde, inicialmente as únicas colonizadas do arquipélago, assim como as de São Tomé e do Príncipe, por colonos brancos e escravos africanos do continente. Para todos os novos habitantes, brancos e escravos africanos, as novas terras eram ambientes desconhecidos. Os dois arquipélagos foram os primeiros territórios em que europeus e africanos conviveram permanentemente. Devido à ausência de mulheres brancas, a união entre homens europeus e escravas africanas era frequente. A mestiçagem, biológica e cultural, entre brancos e negros nos dois arquipélagos resultou na emergência das sociedades crioulas.

O modelo da colonização e da administração aplicado pelos portugueses nesses arquipélagos nos séculos XV e XVI era muito semelhante. Contudo, a posição geoestratégica diferente e, relacionada com ela, a

\footnotetext{
* Pesquisador do Centro de Estudos Internacionais (CEI) do Instituto Universitário de Lisboa (ISCTE-IUL).mailseibert@yahoo.com. Agradeço à Naduska Palmeira, leitora brasileira no Instituto Superior Politécnico (ISP) de São Tomé e Príncipe, a revisão do texto português.
} 
diferença do clima e do meio ambiente entre Cabo Verde e São Tomé e Príncipe condicionaram o estabelecimento de economias distintas e de diferenças no grau de mestiçagem biológica. Isso, por sua vez, resultou em padrões de escravatura e em características de mestiçagem cultural divergentes.

A recolonização de São Tomé e Príncipe, no século XIX, e as transformações socioeconómicas que dela resultaram reforçaram, ainda, as diferenças entre as duas sociedades crioulas. Tais processos históricos de crioulização levaram à afirmação de identidades culturais e políticas distintas entre Cabo Verde e São Tomé e Príncipe. Os cabo-verdianos afirmam ser o "resultado" de um caso particular da colonização portuguesa e consideram-se uma nação crioula. O kaboverdianu é a língua materna de todos e é falada concomitantemente com o português, o que culminou numa situação de diglossia. Também os símbolos nacionais de Cabo Verde refletem as particularidades culturais do país.

Em contraste, e apesar da percepção das diferenças culturais em relação às sociedades continentais, os são-tomenses consideram-se africanos. Além disso, em São Tomé e Príncipe o português é mais falado e valorizado do que o forro, o crioulo local maioritário. Ali a crioulidade não se encontra nos símbolos nacionais cujas referências são africanas.

Essas situações divergentes coincidem também com opiniões dominantes sobre as duas ex-colónias em Portugal. Representativo nesse contexto é o ex-primeiro ministro e ex-presidente português Mário Soares (1924-...) que, em 2005, qualificou Cabo Verde como "a melhor expressão das sínteses culturais que a experiência euromundista produziu", enquanto, em 2008, depois de uma visita a São Tomé para comemorar o $40^{\circ}$ aniversário da sua deportação pelo regime salazarista para a ilha, o mesmo classificou-a apenas como "grande produtora de cana-de-açúcar" e "entreposto de escravos". ${ }^{1}$ Este artigo visa a analisar os diferentes processos históricos de crioulização e suas respectivas consequências identitárias nas duas sociedades crioulas.

Petição Cabo Verde na Europa, 16 de março de 2005. Quarenta Anos Depois, Diário de Notícias, $1^{\circ}$ de julho de 2008.

42 Afro-Ásia, 49 (2014), 41-70 


\section{Processo de crioulização}

A crioulização, frequentemente referida como mestiçagem cultural ou caldeamento cultural na literatura em português, é um termo proveniente da linguística. Nas ciências sociais, não existe uma definição consensual do conceito, visto que processos de mistura cultural distintos em contextos históricos diferentes foram considerados casos de crioulização. ${ }^{2}$ Knörr propõe uma definição mais restrita, que limita crioulização a "um processo em que pessoas etnicamente diversas se tornam indigenizadas e desenvolvem uma nova identidade coletiva carregando (diversos graus de) referência étnica". ${ }^{3}$ Isso significa que, durante o processo, identidades étnicas anteriores desaparecem e são substituídas por uma única nova identidade étnica.

Segundo Chaudenson (2001), o processo de crioulização (linguística) ocorreu em duas fases consecutivas. A primeira fase, chamada de sociedade de habitação, foi dominada por pequenas unidades de produção e uma maior aproximação entre colonos e negros, que eram poucos e não ultrapassavam o número de brancos. A segunda fase, a da sociedade de plantação, foi marcada pelas culturas de exportação, pela organização agroindustrial da produção e por uma maior distância social entre senhores e escravos, que constituíam a grande maioria da população. Nessa fase, os escravos tinham pouco contato direto com a minoria branca. Os recém-chegados, conhecidos por "escravos boçais", já não eram socializados por colonos europeus, mas sobretudo pelos escravos crioulos, mas a mudança de uma fase para a outra não ocorria de forma abrupta ou absoluta. Durante a sociedade de habitação, já existiam plantações, enquanto pequenas propriedades continuaram a existir durante a sociedade de plantação.

Geralmente, pode-se constatar que a matriz e as estruturas das culturas e das sociedades crioulas são europeias e que os africanos imprimiram marcas importantes nos seus conteúdos. Portanto, os escravos

Sobre o debate acerca de teorias de crioulização, ver também Stephan Palmié, "Creolization and Its Discontents", The Annual Review of Anthropology, n. 35 (2006), pp. 433-56.

Jaqueline Knörr, Towards Conceptualizing Creolization and Creoleness. Working Paper No. 100. Halle/Saale: Max Planck Institute for Social Anthropology, 2008, p. 5. 
africanos que partilhavam certos conceitos comuns, conseguiam manter os seus conhecimentos, os seus conceitos e crenças, sobretudo em relação à sua vida privada e caseira, que era menos submetida ao controlo dos colonizadores brancos, sobretudo na sociedade de plantação. A música foi o único domínio em que tradições europeias e africanas sobreviveram e influenciaram-se mutuamente, visto que os cantos, a música e a dança dos escravos eram permitidos ou tolerados em várias circunstâncias. ${ }^{4}$ Também no nível da cultura material, as contribuições africanas foram significativas, porque muitas vezes se adaptaram melhor ao ambiente natural das colónias tropicais (agricultura, pesca, construção de casas, alimentação e uso de plantas medicinais). ${ }^{5}$

Como os escravos africanos provinham de regiões e etnias diferentes, também a sua bagagem cultural era relativamente diversa. Em comparação, a cultura dos brancos, na sua maioria portugueses, era, porém, relativamente homogénea. Ademais, em vista do monopólio do poder político, os africanos não podiam desenvolver e estabelecer as suas próprias instituições e a sua legislação fora dos parâmetros fixados pelos portugueses. Como resultado, o sistema de parentesco e a organização económica, religiosa e política dos africanos não sobreviveram no novo ambiente. Pela mesma razão, desapareceu parte da sua cultura material, assim como técnicas de forja e escultura. Uma exceção, no caso de Cabo Verde, foi a tecelagem importada da Guiné, onde eram produzidos os panos de algodão, objetos principais de permuta no tráfico de escravos na costa vizinha. Além disso, os africanos, nos dois arquipélagos, foram evangelizados pela Igreja Católica, e os seus nomes foram substituídos por nomes portugueses, afastando-se, assim, os escravos das suas culturas de origem.

$\mathrm{O}$ encontro direto e prolongado entre a cultura portuguesa e as várias culturas africanas nos dois arquipélagos gerou um processo de aculturação mútua: uma europeização dos africanos, bem como uma africanização dos europeus, o que resultou na emergência de duas sociedades crioulas com as suas próprias línguas e culturas. O processo

\footnotetext{
4 Robert Chaudenson, Creolization of Language and Culture, Londres/Nova Iorque: Routledge, 2001, p. 306

5 Chaudenson, Creolization, p. 310.

44 Afro-Ásia, 49 (2014), 41-70
} 
de crioulização ocorrido nos dois arquipélagos corresponde à definição do conceito proposto por Knörr, pois as diversas identidades étnicas anteriores perderam-se e foram sendo substituídas por novas identidades coletivas. Integrando-se em culturas únicas, todos os diversos elementos culturais ficaram sujeitos a modificações, e novos elementos vindos dos ambientes locais foram igualmente incorporados às culturas crioulas. Em tais culturas, continuidades diretas e formais com a África foram mais exceções do que propriamente regra. ${ }^{6}$

No âmbito da expansão portuguesa em África, o processo da crioulização em espaços insulares anteriormente desabitados foi bem diferente dos processos de aculturação de elementos ocidentais nas sociedades continentais. No último caso, tratou-se da interação entre europeus e as sociedades já existentes, enquanto nas ilhas, desabitadas, a expansão marítima esteve na base da origem de novas sociedades. Para todos os primeiros habitantes de Cabo Verde e de São Tomé e Príncipe o espaço e o ambiente eram desconhecidos, e o processo da crioulização no novo território ocorreu no contexto de desigualdade entre os brancos e os africanos. No que diz respeito a Cabo Verde, Fernandes confirma que o grau, a natureza e a incidência das perdas variam conforme os grupos envolvidos: "Para os dominantes, trata-se de uma perda auto-consentida, estratégica e provisória, para os dominados ela é heteroinduzida, compulsória e definitiva".

Nos dois arquipélagos, o clima, a insalubridade, a falta de recursos naturais e a distância em relação a Portugal impediram a imigração de brancos em números consideráveis. Isso distingue a colonização de Cabo Verde e de São Tomé e Príncipe da colonização da Madeira, dos Açores e das Canárias, que foram maioritariamente povoados por europeus. Cabo Verde, com o seu clima árido ou semiárido e com chuvas irregulares, possuía condições difíceis, tanto para os europeus como para os africanos provenientes dos Rios da Guiné. ${ }^{8}$ Em comparação, o clima

${ }^{6}$ Sidney W. Mintz e Richard Price, An Anthropological Approach to the Afro-American Past: a Caribbean Perspective, Filadelfia: Institute for the Study of Human Issues, 1976, p. 31.

7 Gabriel Fernandes, Em busca da nação: notas para uma reinterpretação do Cabo Verde crioulo, Florianópolis: Editora da UFSC, 2006, p. 60.

8 Designação para a área geográfica que vai do atual Senegal até à atual Serra Leoa, uma zona que estava ligada a Cabo Verde por meio do comércio, sobretudo o tráfico de escravos. Em inglês, esta área é hoje conhecida por Upper Guinea Coast. 
tropical, quente e úmido, a abundância de chuva e a vegetação exuberante de São Tomé e Príncipe eram ainda mais hostis para os brancos, por causa das doenças tropicais frequentes em tal ambiente. Por outro lado, para os escravos africanos em São Tomé e Príncipe, oriundos do delta do rio Níger (até 1553), do Congo e de Angola, o clima e a natureza do arquipélago não eram tão diferentes das suas terras de origem, como eram no caso de Cabo Verde. Essas condições naturais nos arquipélagos tinham consequências inevitáveis na organização das populações e no desenvolvimento das economias locais.

\section{Povoamento e colonização}

Em Santiago, o povoamento iniciou-se em 1462, cerca de dois anos depois da descoberta do arquipélago. A colonização do Fogo começou nos fins do século XV. Durante muito tempo, Santiago e Fogo eram as únicas ilhas habitadas de Cabo Verde, visto que as demais foram colonizadas posteriormente. Inicialmente, algumas foram utilizadas para a criação de cabras. ${ }^{9}$

Depois de uma primeira tentativa de colonização de São Tomé, em 1486, ter falhado, provavelmente pela falta de produtos alimentares e pela mortalidade dos colonos por doenças tropicais, a colonização efetiva começou a partir de 1493. A colonização do Príncipe seguiu por volta de $1500 .{ }^{10}$ Os padrões de povoamento e de ocupação do espaço, assim como a estratégia económica aplicada nos dois arquipélagos foram

\footnotetext{
9 Sobre a colonização de Cabo Verde, ver: Elisa Silva Andrade, As ilhas de Cabo Verde: da «descoberta» à independência nacional (1460-1975), Paris: L'Harmattan, 1996; António Carreira, Cabo Verde: formação e extinção de uma sociedade escravocrata (1460-1878), Praia: Instituto de Promoção Cultural, 2000; Maria Emília Madeira Santos, Maria Manuel Ferraz Torrão e Maria João Soares (orgs.), História concisa de Cabo Verde (Lisboa: Instituto de Investigação Científica Tropical; Praia: Instituto da Investigação e do Património Culturais, 2007).

10 Sobre a colonização de São Tomé e Príncipe, ver: Robert Garfield, A History of São Tomé Island 1470-1655: The Key to Guinea, São Francisco: Mellen Research University Press, 1992; Arlindo Manuel Caldeira, Mulheres, sexualidade e casamento no arquipélago de S. Tomé e Príncipe (séculos XV a XVIII), Lisboa: Grupo de Trabalho do Ministério de Educação para as Comemorações dos Descobrimentos Portugueses, 1997; Isabel Castro Henriques, São Tomé e Príncipe: a invenção de uma sociedade, Lisboa: Vega, 2000; Artur Teodoro de Matos (coord.), A colonização atlântica, tomo 2 (Lisboa: Estampa, 2005); Izequiel Batista de Sousa, São Tomé et Príncipe de 1485 à 1755 : une société coloniale du blanc au noir, Paris: L'Harmattan, 2008.
}

46 Afro-Ásia, 49 (2014), 41-70 
quase iguais, o que levou o geógrafo Francisco Tenreiro a chamá-los "esquema de uma evolução conjunta". ${ }^{11}$ Esses padrões baseiam-se nas seguintes características:

- instituição inicial de donatários com poderes administrativos e judiciais; dados;

- reduzido número de colonos brancos, muitos dos quais degre-

- povoamento sobretudo com escravos africanos do continente, que serviam de mão de obra; concessão aos moradores de direitos de comércio com a costa vizinha;

- introdução de culturas alimentares e animais domésticos, seguida da cana-de-açúcar;

- estabelecimento de entreposto de tráfico de escravos;

- mestiçagem biológica entre homens brancos e mulheres negras;

- alforria coletiva e individual de escravos; livres;

- ocupação de cargos públicos e religiosos por mulatos e negros

- evangelização pela Igreja Católica.

Durante os primeiros dois séculos de colonização, os dois arquipélagos também sofreram os mesmos problemas, nomeadamente:

- instabilidade política causada por constantes lutas e intrigas entre o governador, a Câmara Municipal e a Igreja Católica local;

- fuga de escravos e assaltos por esses fugitivos;

- ataques e saques de piratas e corsários estrangeiros (a partir dos fins do século XVI); XVII. ${ }^{12}$

- declínio económico e êxodo dos brancos nos meados do século

Para atrair colonos para Cabo Verde, o rei emitiu um decreto em 1466 concedendo aos moradores de Santiago privilégios no comércio

11 Francisco Tenreiro, "Cabo Verde e S. Tomé e Príncipe: esquema de uma evolução conjunta", Boletim de Propaganda e Informação, v. 5, n. 76 (1956), pp. 12-7.

12 Carreira, Cabo Verde, p. 25. 
com a costa da Guiné, que englobava uma área do Senegal até a Serra Leoa. Em 1472, um outro decreto obrigou os moradores em Santiago a fazerem comércio com produtos locais, incentivando a produção local e, por sua vez, o resgate de escravos como mão de obra.

A primeira povoação em Cabo Verde foi Ribeira Grande, em Santiago, que foi também o primeiro povoamento europeu permanente nos trópicos, elevado, em 1533, à categoria de cidade. Em 1513, a população branca da Ribeira Grande era estimada em 170 habitantes. Em 1582, tal número havia aumentado para $508 .{ }^{13}$ Naquela altura, italianos, espanhóis e novos cristãos constituíam uma parte considerável dos povoadores brancos. A maioria dos escravos levados para Cabo Verde provinha das etnias wolof, bambara, fula e mandinga. Em São Tomé, por sua vez, a primeira povoação no nordeste da ilha foi promovida a cidade, homónima, em 1535.

A convivência entre europeus e escravos africanos resultou na emergência de sociedades e de línguas crioulas nos dois arquipélagos. A ausência de mulheres brancas favoreceu as uniões entre brancos e africanas, resultando numa mestiçagem biológica que originou uma nova categoria racial, os mestiços. Também a concessão do acesso a cargos públicos para mulatos no século XVI era uma consequência da falta de um número significativo da população europeia. Pela mesma razão, desde 1548, nos dois arquipélagos, a Câmara Municipal, dominada por filhos da terra, podia substituir o governador no caso da sua morte. Entretanto, em 1770, o marquês de Pombal acabou com essa regra, para reforçar o controlo político de Lisboa.

Existem outras coincidências relativamente a várias datas marcantes da colonização de Cabo Verde e de São Tomé, o que demonstra estratégias semelhantes dos portugueses para as duas colónias àquela altura.

\section{Desenvolvimentos divergentes}

\section{Economia}

As diferenças na posição geográfica e no clima condicionaram divergên-

\footnotetext{
13 António Leão Correia e Silva, Histórias de um Sahel insular, Praia: Spleen, 1996, p. 40.
}

48 Afro-Ásia, 49 (2014), 41-70 


\begin{tabular}{|lcc|}
\hline Dados históricos & Cabo Verde & São Tomé \\
\hline Descoberta & c.1460 & c.1470 \\
Fundação da primeira povoação & 1462 - Ribeira Grande & 1493 - São Tomé \\
Elevação à categoria de cidade & 1533 & 1535 \\
Criação de um bispado & 1533 & 1534 \\
Presença de mestiços na administração & 1546 & $1546(1528)$ \\
Substituição do governador pela Câmara & $1548-1770$ & $1548-1770$ \\
Construção de uma fortaleza & 1591 & 1574 \\
\hline
\end{tabular}

Quadro 1 - Cabo Verde e São Tomé e Príncipe: convergências de dados históricos

cias no que diz respeito ao desenvolvimento da economia e das sociedades de Cabo Verde e de São Tomé e Príncipe, o que, finalmente, levará à afirmação de que há identidades diferentes nas duas sociedades crioulas.

As condições climáticas em Santiago e no Fogo não permitiam o estabelecimento de grandes plantações de cana-de-açúcar, por exemplo, o que impediu o desenvolvimento dessa monocultura. Nos dois primeiros séculos da sua colonização, a economia de Cabo Verde baseou-se principalmente no tráfico de escravos que foram resgatados nos Rios da Guiné e vendidos para a Europa e para as Américas. Foi o tráfico de escravos que criou em Santiago e no Fogo uma economia agropecuária relativamente diversificada, produzida em fazendas para a subsistência e para o abastecimento de navios. $\mathrm{O}$ tráfico facilitou também o fornecimento dos produtos de permuta necessários para o resgate dos escravos nos Rios da Guiné, tais como os panos de algodão e os cavalos. A agricultura baseava-se na plantação da cana-de-açúcar, de milho, de legumes e de frutas. A ilha do Fogo tornou-se um centro de produção de algodão. A tecelagem local no Fogo e em Santiago começou em meados do século XVI. ${ }^{14}$ No início da colonização, as ilhas de Boavista, do Maio e de São Nicolau eram apenas utilizadas para a criação de ovelhas, cabras e gado. É de se notar que os

14 António Carreira, Panaria Cabo-Verdiano-Guineense: aspectos históricos e sócio-económicos, Lisboa: Junta de Investigações do Ultramar, 1968, p. 21. 
impostos pagos pelos traficantes de escravos eram uma importante fonte de receitas para Santiago.

Em Cabo Verde, foi a perda gradual do monopólio do tráfico de escravos com os Rios da Guiné, a partir dos fins do século XVI, que resultou no declínio económico e na degradação da Ribeira Grande. O decreto de 1647 legalizou definitivamente o comércio direto entre os traficantes estabelecidos na costa da Guiné e os mercados de escravos das Américas, medida que resultou também na perda das receitas fiscais, pois os impostos já não eram pagos em Santiago mas em Cacheu. Consequentemente, os morgados em Santiago não conseguiam mais vender os seus produtos. Ainda, pela incapacidade de explorar os latifúndios, os proprietários viram-se forçados a dividi-los em pequenas parcelas arrendadas. A renda podia ser paga em dinheiro ou em géneros. O declínio da Ribeira Grande desencadeou a emigração da elite branca e o êxodo da população citadina para o interior de Santiago. Em consequência dessas mudanças económicas, as fazendas foram gradualmente substituídas por pequenas propriedades para a produção de subsistência.

Também em São Tomé, logo no início da colonização, o tráfico de escravos tinha se tornado importante para a economia local. Contudo, a partir de 1520, o açúcar tornou-se um produto, pelo menos, tão importante quanto o tráfico de escravos na florescente economia são-tomense. Essa foi uma das razões pelas quais os moradores de São Tomé não mantiveram relações tão intensas com a costa do Golfo da Guiné, como os cabo-verdianos sempre tiveram com os Rios da Guiné. Esse território foi governado por Santiago até 1879 , quando se procedeu à separação administrativa, constituindo-se a Guiné Portuguesa. Em contraste, desde o início da sua colonização, no terceiro quartel do século XVI, Angola foi governada diretamente de Lisboa e nunca dependeu politicamente de São Tomé.

Nas ilhas do Golfo da Guiné, o clima tropical e a abundância de chuvas favoreceram o estabelecimento de plantações de cana-de-açúcar. O declínio económico em São Tomé também começou nos fins do século XVI e agravou-se em meados do século XVII, mas as causas eram a competição do açúcar do Brasil, que era de melhor qualidade, e a crescente ameaça dos corsários franceses, ingleses e holandeses no

50 Afro-Ásia, 49 (2014), 41-70 
Atlântico, bem como os assaltos de escravos fugidos para o inacessível interior da ilha - que, mais tarde, seriam conhecidos por "angolares" — às plantações e à cidade de São Tomé.

O fim da indústria de açúcar resultou no êxodo dos brancos que deixaram as terras e os escravos nas mãos dos africanos e mestiços livres. ${ }^{15}$ Antes, no fim do século XVI, São Tomé perdera a sua posição de entreposto de escravos em favor de Luanda. Depois do colapso da indústria de açúcar, a economia de plantação transformou-se numa agricultura de subsistência, cujo excesso serviu para o abastecimento de navios, tendo sido a principal receita comercial na época. Além de ser escala do tráfico transatlântico, São Tomé e Príncipe mantinha ligações com Calabar, com Angola, com a costa do Golfo da Guiné e com o Brasil.

\section{Sociedades escravocratas}

Em São Tomé e Príncipe, depois da fase inicial da sociedade de habitação, o estabelecimento de uma economia de plantação, baseada na monocultura do açúcar, elevou rapidamente o número de escravos de plantação em relação ao de escravos domésticos. Tenreiro afirma que, em meados do século XVI, cada plantação de açúcar tinha em média 150 escravos e que os homens ricos possuíam até 300 escravos. ${ }^{16} \mathrm{Em}$ Cabo Verde, entretanto, sobretudo em Santiago, com uma economia mais diversificada e menores unidades de produção, o número de escravos domésticos, que tinham uma maior proximidade com os moradores brancos, foi dominante. As fazendas tinham cerca de dezenas de escravos que, raramente, chegavam a uma centena. Prevaleceram situações em que o relacionamento entre os europeus e os africanos era parecido com o relacionamento na sociedade de habitação. Em São Tomé, o regime da escravatura doméstica voltou a dominar apenas a partir dos fins do século XVII e persistiu até o início de século XIX, mas, durante esse período, a maior proximidade era entre proprietários crioulos (mestiços e negros) e escravos.

\footnotetext{
15 Pablo B. Eyzaguirre, "Small Farmers and Estates in São Tomé, West Africa" (Tese de Doutorado, Yale University, 1986), p. 92.

${ }^{16}$ Francisco Tenreiro, A ilha de São Tomé, Lisboa: Junta de Investigações do Ultramar, 1961, pp. 63,69 .
} 
Desde o início da colonização, a concessão de alforria a escravos era frequente nas duas sociedades. Em São Tomé, a pedido dos primeiros moradores, o rei emitiu dois decretos de alforria libertando, em 1515, as mulheres escravas dos primeiros moradores assim como os seus filhos e, em 1517, os homens escravos chegados com os primeiros colonos. Frequentemente, as libertações individuais eram concedidas pelos senhores nos seus testamentos por razões de afeto ou gratidão para com os seus escravos. Em São Tomé, o facto de que, desde o século XVIII, a maioria dos donos dos escravos também era constituída por negros facilitou a emancipação de escravos para a categoria dos forros, porém, em Cabo Verde, a libertação de escravos teve números bastante distintos em comparação com São Tomé e Príncipe. As principais causas dessa diferença foram as secas e as consequentes crises económicas que levaram muitos donos a libertar ou simplesmente abandonar os seus escravos, visto que não estavam em condições de sustentá-los. Para evitar a submissão em relação aos proprietários fundiários, muitos desses libertos fixaram-se no interior de Santiago e em ilhas do Barlavento, onde dominava o minifúndio e o regime de sesmaria. Mulatos e negros livres de Santiago e do Fogo foram os primeiros povoadores das demais ilhas do arquipélago.

Uma das maiores diferenças entre os dois arquipélagos eram as secas cíclicas, seguidas pelas crises de fome que atingiam Cabo Verde desde 1580. Durante mais de três séculos, as fomes cíclicas vitimaram milhares de cabo-verdianos. Houve situações terríveis em que um quarto da população morreu de fome. Durante a fome de 1773-1775, que vitimou entre 22.000 e 32.500 pessoas, os ilhéus venderam-se como escravos em troca de alimentos para comerciantes estrangeiros. ${ }^{17}$ As crises de fome não mataram apenas milhares de habitantes, mas também constituíram um fator estruturante da economia e da sociedade do arquipélago, visto que impediram a manutenção de grandes propriedades com muitos escravos e condicionaram a predominância de uma economia de subsistência dominada por pequenos agricultores.

Como resultado das referidas mudanças socioeconómicas em Cabo Verde, a importação de escravos africanos para o arquipélago já

${ }^{17}$ Carreira, Cabo Verde, p. 200.

52 Afro-Ásia, 49 (2014), 41-70 


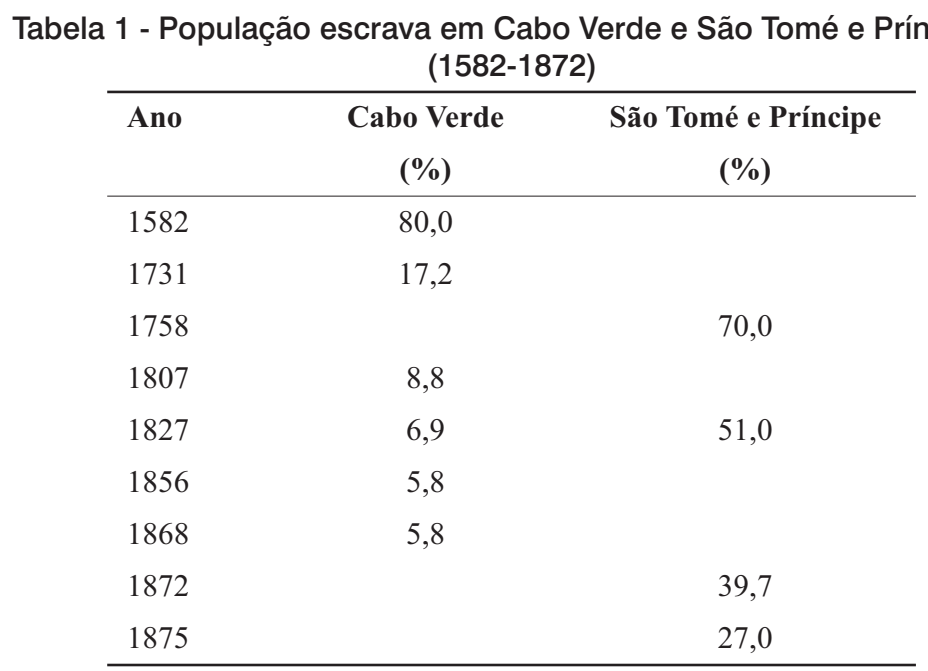

era pouco significativa, mesmo antes da abolição do tráfico de escravos no Império Português, em 1836. Os escravos tornaram-se uma minoria já no decorrer do século XVII. A abolição do tráfico de escravos acabou, finalmente, com a entrada de africanos do continente em Cabo Verde. $\mathrm{O}$ fim da imigração africana forçada também cortou largamente o contato do arquipélago com as culturas africanas. Dos 5.182 escravos recenseados em Cabo Verde em 1856, 82,3\% nasceram no arquipélago. Naquele ano, o número médio de escravos por senhor nas diferentes ilhas variou entre 1,9 em Brava e 4,4 em Santiago e no Fogo. ${ }^{19}$ Por outro lado, em meados do século XVIII, em São Tomé e Príncipe, os escravos representavam mais de dois terços da população e pertenciam, em sua maioria, aos nativos crioulos, os chamados forros, visto que, naquela altura, a presença branca no arquipélago era insignificante. Até a primeira metade do século XIX,

\footnotetext{
18 Carreira, Cabo Verde, p. 397; Augusto Nascimento, Poderes e quotidiano nas roças de S. Tomé e Príncipe: de finais de oitocentos a meados de novecentos, Lisboa: Edição do Autor, 2002, p. 85; João Estêvão, "Cabo Verde", in Valentim Alexandre e Jill Dias (coords.), O império africano, 1825-1890 (Lisboa: Estampa, 1998), p. 193.

19 Carreira, Cabo Verde, p. 425.
} 
predominava a posse de um ou dois escravos, exceto entre os grandes proprietários. Na sua quase totalidade, os escravos não eram naturais, mas imigrantes. ${ }^{20}$ Em São Tomé e Príncipe, com o reaparecimento da economia de plantação, a importação de escravos do continente vizinho continuou depois de 1836 . Oficialmente, os proprietários podiam transferir um máximo de dez escravos, designados "libertos" a partir de 1869 , entre as possessões portuguesas. Os novos colonizadores resgataram em Angola o número máximo de "libertos" previsto na legislação aprovada em consequência das pressões inglesas.

Depois da recolonização e da introdução da categoria dos "libertos", as manumissões se tornaram menos frequentes do que no período anterior de escravatura. ${ }^{21}$ Ao mesmo tempo, as relações escravagistas assemelharam-se cada vez mais ao modelo dominante das plantações nas Américas.

A partir do início da colonização, em ambas as sociedades escravocratas, a fuga dos escravos era um fenómeno recorrente. Grupos de escravos autolibertados, escondidos nas serras de Santiago e na floresta no interior de São Tomé, assaltavam frequentemente as povoações e as plantações. A ameaça desses fujões era tão grande que as autoridades locais se viam forçadas a criar unidades armadas para persegui-los e combatê-los. Ao contrário de Cabo Verde, onde as características climáticas e topográficas das serras de Santiago não permitiram o estabelecimento de uma comunidade estável e permanente de fugitivos (conhecidos por "vadios" ou "badios", em crioulo), em São Tomé, graças à densa floresta no montanhoso sul da ilha, houve um espaço fora do controlo dos portugueses, onde os escravos fugidos conseguiram constituir um quilombo, que viveu relativamente isolado até 1878. No mesmo ano, o território no sul de São Tomé, até então constituído basicamente por tal quilombo, foi ocupado pelo poder colonial em decorrência da necessidade de continuar a expandir a economia de plantação pelos agricultores portugueses por outras regiões da ilha. Como já referido, os descendentes dos antigos fugitivos são conhecidos em São Tomé por angolares. Graças

\footnotetext{
20 Augusto Nascimento, "S. Tomé e Príncipe", in Valentim Alexandre e Jill Dias (coords.), $O$ império africano, 1825-1890 (Lisboa: Estampa, 1998), p. 287.

21 Nascimento, "S. Tomé e Príncipe", p. 289.

54 Afro-Ásia, 49 (2014), 41-70
} 
ao seu isolamento prolongado, até hoje constituem um grupo cultural e linguisticamente distinto na ilha.

\section{Diferenças na situação linguística}

As diferenças na situação linguística nas duas sociedades crioulas devem-se, primordialmente, às diferentes características geográficas dos dois arquipélagos. As línguas crioulas, que são o resultado de uma forma específica de contato entre línguas, nasceram durante as primeiras décadas da colonização, facilitando a comunicação entre os africanos, que falavam várias línguas diferentes, e entre eles e os colonos portugueses. A crioulização ocorreu, em primeiro lugar, como resultado da mudança da sociedade de habitação para a de plantação, quando a situação em que o contato direto entre brancos e escravos foi substituída por outra, em que os escravos crioulos passaram a constituir um grupo intermediário entre brancos e "escravos boçais", os recém-chegados. ${ }^{22}$ Tipicamente, a crioulização linguística foi marcada por três características, quais sejam: ter emergido em ilhas; ter se desenvolvido em cerca de um século; e ter evoluído em comunidades de escravos. ${ }^{23}$ Nos dois casos concretos de Cabo Verde e São Tomé e Príncipe, a língua socialmente dominante, o português, fornecia a esses crioulos a base lexical.

Em Cabo Verde, emergiu um crioulo, o kabuverdianu ou, simplesmente, crioulo, com variações locais. ${ }^{24}$ Um documento datado de $1558^{25}$ mencionou, pela primeira vez, escravos que falavam crioulo, crioulo esse que se consolidou nos séculos XVII e XVIII. ${ }^{26}$ De outra forma, graças à maior distância entre as duas e ao isolamento dos angolares, em São Tomé e Príncipe, embora contando com uma superfície total muito menor que a de Cabo Verde, desenvolveram-se três crioulos distintos, nomeadamente: na ilha de São Tomé, a lungwa santome ou forro, o crioulo maioritário, e o angolar (ngola) e, no Príncipe, o lung'yie. Os três crioulos são mutu-

22 Chaudenson, Creolization, p. 138.

Chaudenson, Creolization, p. 34.

Sobretudo entre Sotavento e Barlavento.

Carreira, Cabo Verde, p. 316.

26 Manuel Veiga, "O crioulo de Cabo Verde: emergência e afirmação", in Descoberta das ilhas de Cabo Verde, Praia: Arquivo Histórico Nacional, 1998, p. 116. 
amente ininteligíveis, embora partilhem um número substancial de propriedades lexicais e gramaticais, pois partiram de uma base comum, um protocrioulo, falado inicialmente em São Tomé. ${ }^{27}$ Os crioulos do Golfo da Guiné desenvolveram-se separadamente daquele de Cabo Verde. Tais línguas foram importantes para a difusão e a transmissão de elementos da cultura crioula. Por outro lado, o rápido desaparecimento das línguas africanas faladas anteriormente pelos escravos impediu a sobrevivência de muitos elementos das suas culturas originais. ${ }^{28}$

O forro é um crioulo mais radical, o que significa que é mais afastado do português do que o kabuverdianu. Os escravos em Cabo Verde provinham de 19 grupos etnolinguísticos, no entanto, menos de $1 \%$ do vocabulário do seu crioulo é de origem africana. Os de origem africana são, sobretudo, mandinga (58\%), wolof (20\%) e temne (5\%). No caso do forro, os vocábulos de origem africana vêm do edo (37\%) e das línguas banto, o quicongo e ambundo (63\%) e representam cerca de $10 \%$ do seu léxico. ${ }^{29}$

\section{Brancos e mestiços}

Devido ao clima em São Tomé e Príncipe, as doenças tropicais constituíam maior ameaça para os habitantes brancos do que em Cabo Verde. No início do século XVI, o número de brancos em Cabo Verde era pouco maior que 100. Nos finais do mesmo século, não chegou a um milhar. ${ }^{30}$ A alta taxa de mortalidade dos brancos foi uma das razões pelas quais, no início da colonização, a Coroa portuguesa facilitava as uniões entre homens brancos e escravas africanas em São Tomé e, pela mesma razão, em 1515 e 1517, decretou-se a alforria coletiva de escravos africanos. Depois do declínio económico, no século XVII, a percentagem da po-

\footnotetext{
27 João Pontífice, Caustrino Alcântara, Beatriz de Castro Afonso, Tjerk Hagemeijer e Philippe Maurer, Alfabeto Unificado para a Escrita das Línguas Nativas de S. Tomé e Príncipe (ALUSTP), 2010.

28 Chaudenson, Creolization, 309.

29 John Ladham, "The Formation of the Portuguese Plantation Creoles" (Tese de Doutorado, University of Westminster, 2003), pp. 144, 155.

30 Ilídio Baleno, "A afirmação da sociedade cabo-verdiana a partir da crise dos séculos XVII e XVIII", in Jürgen Lang, John Holm, Jean-Louis Rougé e Maria João Soares (orgs.), Cabo Verde. origens da sua sociedade e do seu crioulo (Tübingen: Gunter Narr Verlag, 2006), p. 151.
}

56 Afro-Ásia, 49 (2014), 41-70 


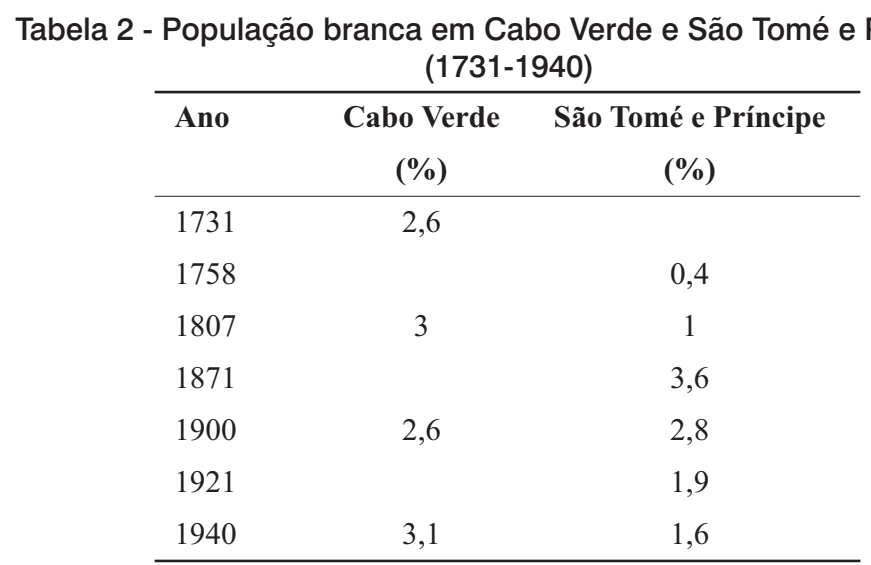

pulação branca era muito diminuta nos dois arquipélagos. Porém, em comparação, em vista da maior incidência das doenças tropicais e da falta de interesse econômico em São Tomé e Príncipe, a presença da população branca era mais reduzida ainda. Em 1758, havia 53 brancos em São Tomé e Príncipe, todos considerados "brancos de fora", que representavam $0,4 \%$ de uma população de 12.772 habitantes.

Em 1807, a população branca aumentara para 121 pessoas, que representavam $1 \%$ da população de São Tomé e Príncipe. ${ }^{32}$ No entanto, quando, no terceiro quartel do século XIX, a expansão da economia de plantação resultou num aumento da população branca para 3,6\%, o grau da mestiçagem era muito menor do que no século XVI, visto que muitos brancos levaram as suas mulheres para as ilhas. Além disso, ao contrário de Cabo Verde, onde sempre houve "brancos de terra", sobretudo no Fogo e, mais tarde, nas ilhas do Barlavento, em São Tomé e Príncipe nunca houve uma pequena comunidade branca autóctone, pois os poucos brancos, na sua maioria degredados, ficaram temporariamente lá.

A maior percentagem da população mestiça em Cabo Verde está

31 Neves, S. Tomé e Príncipe, p. 177; Nascimento, Poderes e quotidiano, pp. 85, 137; Estêvão, "Cabo Verde", p. 193.

32 Carlos Agostinho das Neves, S. Tomé e Príncipe na segunda metade do séc. XVIII, Funchal: Região Autónoma da Madeira, 1986, p. 177. 
relacionada com os fatores demográficos ora mencionados. Graças a um maior número de brancos e, possivelmente, à endogamia entre os mestiços, a percentagem destes últimos na população aumentou gradualmente e, segundo as estatísticas, desde o século XIX, a maior parte da população cabo-verdiana já era mestiça. De facto, em Cabo Verde, embora reduzida, a afluência dos brancos foi uma constante durante séculos, inclusive depois do colapso económico no século XVII. Além disso, os brancos não iam para as ilhas provindos apenas de Portugal, mas de vários outros lugares do mundo. Durante o século XVIII, por exemplo, imigrantes judeus do Marrocos e de Gibraltar, espanhóis das Canárias e outros estrangeiros estabeleceram-se no Barlavento, mais precisamente em Santo Antão, Boavista, Sal e São Nicolau. Posteriormente, os mesmos migraram para São Vicente, onde deram um incentivo decisivo ao ambiente cosmopolita e ao desenvolvimento local da ilha. ${ }^{33}$ As origens diversas da imigração branca são, sobretudo, relevantes para a diversificação das influências culturais na sociedade cabo-verdiana. Entre 1802 e 1882, Portugal mandou 2.433 degredados para Cabo Verde, entre os quais 81 mulheres, que teriam contribuído consideravelmente para a mestiçagem biológica no arquipélago ${ }^{34}$ Travassos Valdez, que visitou Cabo Verde nos meados do século XIX, contou cerca de 100 brancos em São Nicolau, 400 em Boa Vista (a maior percentagem de brancos em todas as ilhas do arquipélago), e mais de 1.000 brancos em Santiago. ${ }^{35}$

Em São Tomé e Príncipe, depois do colapso da indústria do açúcar, aconteceu o contrário. A imigração de brancos quase parou, enquanto a população se reafricanizou geneticamente por meio da mestiçagem entre africanos. Por outro lado, em termos culturais e linguísticos, uma reafricanização era impossível, visto que a sociedade e a cultura crioulas estavam já bem estabelecidas. A parte da herança genética europeia dos mestiços diluiu-se em sucessivas gerações. ${ }^{36}$ Por isso, a afirmação de Tenreiro de que, no início do século XIX, o elemento preponderante da

\footnotetext{
Onésimo Silveira, A democracia em Cabo Verde, Lisboa: Colibri, 2005, p. 101.

34 Carreira, Cabo Verde, p. 336.

35 Francisco Travassos Valdez, Six Years of a Traveller's Life in Western Africa, v. 1, Chestnut Hill, Ma.: Adamant Media Corporation, 2005 [1861], pp. 61, 77, 128.

36 Eyzaguirre, "Small Farmers", p. 103.

58 Afro-Ásia, 49 (2014), 41-70
} 


\begin{tabular}{|c|c|c|}
\hline Ano & $\begin{array}{c}\text { Cabo Verde } \\
(\%)\end{array}$ & $\begin{array}{c}\text { São Tomé e Príncipe } \\
(\%)\end{array}$ \\
\hline 1731 & 29.1 & \\
\hline 1807 & 41.5 & 3.3 \\
\hline 1843 & & 1.5 \\
\hline 1900 & 64.2 & \\
\hline 1940 & 64.5 & \\
\hline 1950 & 69.6 & 7.1 \\
\hline
\end{tabular}

população era o mestiço é falsa em termos genéticos. ${ }^{38} \mathrm{O}$ governador Vicente Pinheiro (1852-1853) escreveu sobre tal aspeto, afirmando que

[...] esta descendência [dos ilhéus] é de escravos alforriados, e produto, remoto ou recente, do cruzamento de raça africana com raça branca. Este último elemento não deixa de ser importante, com quanto poucas vezes provenha de geração próxima, e assim se explicam as semelhanças fisionómicas com a nossa raça, que vulgarmente se encontram no filho de S. Tomé, mesmo quando a cor não caracteriza a sua origem mestiça. ${ }^{39}$

Consequentemente, no século XIX, em São Tomé e Príncipe, não apenas a maioria da população era negra, mas também a elite local, enquanto em Cabo Verde, na mesma altura, a maioria da população era mestiça e a elite era mulata e branca. Ilustrativo dessa diferença é o facto de que o jornalista e poeta cabo-verdiano Eugénio Tavares (1867-1930), considerado como um dos pais da cabo-verdianidade, era um branco de ascendência italiana-espanhola-lusa, enquanto o seu contemporâneo, o primeiro poeta são-tomense, Caetano da Costa Alegre (1864-1890), era um crioulo negro.

\footnotetext{
37 Estêvão, "Cabo Verde", p. 193; Neves, S. Tomé e Príncipe, p. 177; Tenreiro, A ilha de São Tomé, p. 102.

38 Vicente Pinheiro, S. Thome e Príncipe, Lisboa: Academia Real das Ciências, 1884, p. 6.

39 Tenreiro, A ilha de São Tomé, p. 77.
} 
Essas divergências no processo de mestiçagem levaram António Carreira a concluir que

[...] nas [ilhas] de Cabo Verde, dentro da sua extrema pobreza, a miscigenação prosseguiu sem paragens, levando à formação de uma comunidade com costumes, hábitos, comportamentos e língua fundamentalmente portugueses, ao passo que nas de $\mathrm{S}$. Tomé, segundo parece, os resultados dos contactos raciais e culturais podem ser considerados insignificantes se os compararmos com os atingidos naquele arquipélago. ${ }^{40}$

Pesquisas genéticas recentes confirmam as diferenças em termos da mestiçagem biológica: o nível da miscigenação em São Tomé é 0,065 , sendo mais baixo do que níveis encontrados em populações afro-americanas e muito mais baixo do que uma estimativa de 0,363 para Cabo Verde. ${ }^{41}$

\section{Mudanças socioeconómicas no século XIX}

Mudanças e desenvolvimentos ocorridos no século XIX acentuaram as diferenças já existentes entre as duas sociedades crioulas. Em São Tomé e Príncipe, a introdução do café, em 1789, e do cacau, por volta de 1821, facilitou uma recolonização do arquipélago pelos portugueses no contexto do colonialismo moderno. Até a década de 1840, São Tomé praticamente se autogovernou. ${ }^{42}$ Os forros, com exceção de uns grandes proprietários, empregavam-se na administração, dedicavam-se a serviços urbanos e eram pequenos proprietários, rendeiros ou sub-rendeiros das roças do Estado ou de particulares. ${ }^{43} \mathrm{~A}$ subsequente expansão das plantações de café e de cacau, na segunda metade do século XIX, resultou gradualmente na marginalização política e económica dos forros, que perderam a sua posição dominante, ocupada desde o colapso da indústria de açúcar, e foram relegados para uma posição intermediária numa hierarquia colonial, então dominada por brancos metropolitanos. Ainda

\footnotetext{
40 Carreira, Cabo Verde, p. 25.

41 Gil Tomás et al., "The Peopling of São Tomé (Gulf of Guinea): Origins of Slave Settlers and Admixture with the Portuguese", Human Biology, v. 74, n. 3 (2002), p. 408.

42 Nascimento, "S. Tomé e Príncipe", p. 272.

43 Nascimento, "S. Tomé e Príncipe", p. 277.

60 Afro-Ásia, 49 (2014), 41-70
} 
em 1878, a maior parte dos 1.014 proprietários era natural das ilhas, mas quase todos os grandes agricultores eram europeus. Em meados da década de 1890, o número de grandes roças na posse de investidores brancos tinha triplicado. ${ }^{44}$

Depois da abolição da escravatura, em 1875, os portugueses recrutaram, em Angola (desde 1876), Cabo Verde (1903) e Moçambique (1908), mão de obra para as plantações. A população nativa, os forros e os angolares, sempre se recusaram a aceitar "o trabalho escravo" nas plantações, pois o consideravam abaixo do seu estatuto de africanos livres. Além disso, a população local era insuficiente para satisfazer a procura de mão de obra. Desde os fins do século XIX até os anos de 1940, os contratados africanos, chamados serviçais, que constituíam uma nova categoria social no arquipélago, ultrapassaram demograficamente os ilhéus. Em contraste com Cabo Verde, São Tomé e Príncipe nunca ficou afastado das culturas africanas, nem depois do fim do tráfico de escravos e da abolição da escravatura. Os contratados viviam nas senzalas das plantações, espacialmente separados dos ilhéus, que os excluíam da sua vida social e cultural. O restabelecimento da economia de plantação, na segunda metade do século XIX, criou, em São Tomé e Príncipe, uma sociedade plural, em que os grupos viviam separados segundo regras sociais diferentes. A segunda colonização, a marginalização dos forros e o aparecimento de uma sociedade plural impediram uma consolidação da sociedade crioula são-tomense.

Também Cabo Verde conheceu, no século XIX, importantes mudanças socioeconómicas, porém em contextos bem distintos. Os principais fatores dessas mudanças foram a abolição do regime de morgadio em 1863, o início da emigração moderna, a abolição da escravatura em 1876 e o estabelecimento do sistema colonial moderno. ${ }^{45}$ Foi a abolição dos morgadios que, definitivamente, tornou a agricultura cabo-verdiana uma agricultura de pequenos produtores. No mesmo século, Cabo Verde também viu uma revalidação da sua posição geoestratégica e um crescimento económico, graças ao estabelecimento da estação de carvão para

\footnotetext{
44 Nascimento, "S. Tomé e Príncipe”, pp. 303-4.

45 Estêvão, "Cabo Verde", p. 185.
} 
o abastecimento da navegação a vapor pelos ingleses no Porto Grande (Mindelo), em São Vicente, onde a colonização começara apenas em 1795. Em 1838, a empresa britânica East India Company abriu a primeira estação de carvão no Mindelo, e, até 1896, várias outras empresas britânicas estabeleceram lá tais estações. No entanto, já depois da abertura do canal de Suez em 1869, o trânsito marítimo no Atlântico começou a diminuir e, na altura da I Guerra Mundial, o declínio foi significativo. ${ }^{46}$ Entretanto, durante mais de cinquenta anos, as estações de carvão geraram alguma prosperidade para Cabo Verde, que recuperou a importância estratégica perdida nos meados do século XVII. Ao contrário de São Tomé e Príncipe, durante o século XIX, Cabo Verde não foi submetido a uma segunda colonização económica por Portugal.

Ao mesmo tempo em que as ilhas do Golfo da Guiné se tornaram um destino de imigração, começou, em Cabo Verde, uma vaga de emigração, em resposta à miséria em que viviam muitos cabo-verdianos. Inicialmente, emigraram para os Estados Unidos, como consequência da atividade dos baleeiros norte-americanos. Depois, para a Guiné Portuguesa e, mais tarde, para outros destinos. Em 1824, o primeiro cabo-verdiano que havia embarcado num baleeiro e se fixado nos Estados Unidos se tornou cidadão americano. Os cabo-verdianos foram os primeiros africanos que emigraram para os Estados Unidos voluntariamente, e não como escravos. A emigração tornou-se um fator da mudança socioeconómica em Cabo Verde, devido à articulação que se estabeleceu entre o arquipélago e o espaço atlântico. Em 1832, a comunidade cabo-verdiana na Nova Inglaterra enviou a primeira encomenda de alimentos, dinheiro e medicamentos para a sua terra ${ }^{47} \mathrm{Os}$ emigrantes enviaram remessas para as suas famílias, e os que regressaram ao arquipélago fizeram-no em condições económicas diferentes. Os migrantes regressados dos Estados Unidos não levaram apenas dinheiro, mas também conceitos americanos da cultura política e administrativa. Enquanto a recolonização, em São Tomé e Príncipe, resultou na marginalização dos forros e na emergência de uma sociedade plural, a sociedade crioula continuou a consolidar-se em Cabo Verde.

\footnotetext{
46 Luís Batalha, The Cape Verdean Diaspora in Portugal. Colonial Subjects in a Postcolonial World, Lanham: Lexington Books, 2004, p. 27.

47 António Leão Correia e Silva, Cabo Verde: combates pela história, Praia: Spleen, 2004, p. 40.

62 Afro-Ásia, 49 (2014), 41-70
} 
A consolidação da sociedade crioula também resultou no estabelecimento do ensino escolar, cuja grande impulsionadora era a Igreja Católica. Em Cabo Verde, a primeira escola primária estatal foi fundada em 1847, na ilha Brava. Em 1874, existiam 36 escolas primárias para rapazes e nove para raparigas, que eram frequentadas, respetivamente, por 1.800 rapazes e 200 raparigas. Em 1909, esse número aumentou para 50 escolas primárias, das quais onze para raparigas. ${ }^{48}$ Além disso, a fundação do seminário-liceu em São Nicolau, em 1866, e, depois do seu encerramento, em 1917, a criação do Liceu Infante D. Henrique, em São Vicente (rebatizado Liceu Gil Eanes, em 1937), facilitaram a emergência de uma elite intelectual local. A educação tornou-se "um dos pilares emancipatórios da sociedade crioula". ${ }^{49}$ Graças ao liceu, São Vicente tornou-se uma potência cultural. A prosperidade do porto do Mindelo criou uma ligação importante com o mundo, tornando-o, assim, centro cosmopolita e cultural de Cabo Verde. No início do século XX, já havia 4.527 alunos em Cabo Verde, consideravelmente mais do que em Angola (2.185), em Moçambique (1.215) e na Guiné-Bissau (303). ${ }^{50}$ Segundo Fernandes, a educação, a imprensa e a diáspora foram decisivas para minar as bases do colonialismo português e influenciar a emergência do nacionalismo cabo-verdiano. ${ }^{51}$

No período em consideração, em São Tomé e Príncipe, a recolonização atrasou a introdução do ensino escolar. Segundo o censo de 1878 , de uma população total de 20.928 pessoas, entre as quais 8.788 serviçais africanos, apenas 346 sabiam ler e escrever. No mesmo ano, apenas 389 alunos frequentavam a escola nas duas ilhas..$^{52} \mathrm{Em} \mathrm{1881,} \mathrm{o}$ governo colonial em São Tomé decidiu estabelecer uma escola primária em cada uma das dez freguesias e três escolas primárias para raparigas, dentre as quais uma em Príncipe. O primeiro liceu foi fundado muito mais tarde, em 1952. Antes, os estudantes são-tomenses tinham de ir a Portugal para frequentar o ensino secundário. Foram sobretudo os filhos de alguns proprietários forros que, no início do século XX, participaram do boom

\footnotetext{
48 Francisco Mantero, A mão d'obra em S.Thomé e Príncipe, Lisboa: Edição do Autor, 1910, p. 60.

49 Fernandes, Em busca da nação, p. 98.

50 Fernandes, Em busca da nação, p. 110.

Fernandes, Em busca da nação, p. 97.

Pinheiro, S.Thome e Príncipe, p. 66.
} 
do café e do cacau nas ilhas. De 1900 a 1914, cerca de cinquenta jovens são-tomenses frequentaram o liceu e os colégios em Portugal. Muitos estudantes são-tomenses participaram ativamente em jornais e associações pan-africanistas que surgiram durante a Primeira República (1910-1926) em Portugal. Dez dos catorze membros fundadores da Junta de Defesa dos Direitos d'África (JDDA), a primeira organização pan-africanista em Lisboa, fundada em 1912, eram são-tomenses, contando com outros dois membros angolanos e dois cabo-verdianos. Os intelectuais são-tomenses, na sua maioria negros, sentiam-se atraídos pelas ideias do pan-africanismo de William du Bois (1868-1963) e de Marcus Garvey (1887-1940). A participação dos intelectuais cabo-verdianos nessas iniciativas foi relativamente fraca, visto que, naquela altura, assumiram uma identidade própria, "civilizados", mais próximos dos lusos, pois a elite política, intelectual e económica de Cabo Verde era então constituída sobretudo por descendentes de europeus, mestiços ou não, e de portugueses. Em 1953, Tenreiro justificou a ausência de poetas de Cabo Verde no caderno de Poesia negra de expressão portuguesa, pelo facto de que "a poesia das ilhas crioulas, com raríssimas exceções, não traduziam o sentimento da negritude, que era a razão-base da poesia negra". ${ }^{53}$

Foram os intelectuais cabo-verdianos, formados nos liceus locais, que, no início do século XX, denunciaram nos jornais locais as práticas coloniais da dominação portuguesa, época em que a elite cabo-verdiana identificou-se com Portugal e sentiu-se leal à nação portuguesa. Parte dessa afirmação passava pelo distanciamento em relação aos africanos, designados indígenas, e pela afinidade com a nação portuguesa. Os cabo-verdianos opuseram-se à aplicação do estatuto de indígenas, tendo em vista o seu estado de "civilização". Tais intelectuais, conhecidos por nativistas, "construíram um tipo discursivo peculiar, em que a aceitação da nação lusitana convive com a recusa das suas práticas e agentes." 54 Depois do golpe de Estado de maio de 1926 e da institucionalização do Estado Novo, em 1933, diante da censura política, os intelectuais do movimento literário Claridade (1936) valorizaram o crioulo e a cultura

\footnotetext{
53 Francisco Tenreiro e Mário Pinto de Andrade (orgs.), Poesia negra de expressão portuguesa, Linda-a-Velha: África - literatura, arte e cultura, 1982 [1953], p. 82.

54 Fernandes, Em busca da nação, p. 142.

64 Afro-Ásia, 49 (2014), 41-70
} 
cabo-verdianos, para reclamar a particularidade de sua própria identidade no contexto do império colonial português. As publicações desses intelectuais consolidaram a ideia de uma identidade cabo-verdiana distinta. ${ }^{55} \mathrm{~A}$ luta emancipatória dos nativistas e dos claridosos deu aos cabo-verdianos referências para se afirmarem como um povo. Foram os intelectuais da geração claridosa que abraçaram os conceitos do luso-tropicalismo de Gilberto Freyre (1900-1987), visto que consideravam Cabo Verde um resultado bem sucedido da mestiçagem promovida pelos portugueses ${ }^{56}$ Quando os intelectuais cabo-verdianos dos anos 1960 assumiram teoricamente a africanidade no contexto da luta de libertação, conduzida pelo Partido Africano da Independência da Guiné e Cabo Verde (PAIGC), essa "podia conviver com uma cabo-verdianidade [...] lograda no discurso de uma experiência sócio-histórica peculiar." ${ }^{57}$

Curiosamente, o próprio Freyre negou a mestiçagem na história são-tomense quando escreveu, no seu relato sobre uma visita a São Tomé em dezembro de 1951, sem qualquer prova documental, que as ilhas "foram descobertas em 1470 [e que] tinham já sua população negra, sobre a qual começaram a agir, desde o século $\mathrm{XV}$, os missionários portugueses". ${ }^{58}$ Os dois exemplos mostram também o destaque dado à mestiçagem biológica em detrimento da mestiçagem cultural nos conceitos do luso-tropicalismo. Contudo, também em outros discursos, no contexto das Caraíbas, os conceitos de crioulo, crioulização ou crioulidade são ainda muito ligados à ideia de mulatos e mulatização, ou seja, com a mestiçagem biológica. ${ }^{59}$ De facto, em termos culturais, crioulidade não depende de "raça" ou "cor de pele". ${ }^{60}$ Todavia, é este fator "racial", a relação que se faz do crioulo com mulato ou mestiço, que está na base das afirmações identitárias diferentes em Cabo Verde e São Tomé e Príncipe.

\footnotetext{
55 Batalha, The Cape Verdean Diaspora, p. 75.

56 Cláudia Castelo, O modo português de estar no mundo: o luso-tropicalismo e a ideologia colonial portuguesa, Porto: Afrontamento, 1998, p. 81.

57 Fernandes, Em busca da nação, p. 199.

58 Gilberto Freyre, Aventura e rotina: sugestões de uma viagem à procura das constantes portuguesas de carácter e ação, Rio de Janeiro: José Olympio/MEC, 1980 [1953], p. 311.

59 Ulrich Fleischmann, "The Sociocultural and Linguistic Profile of a Concept", in Gordon Collier e Ulrich Fleischmann (eds.), A Pepper-Pot of Cultures: Aspects of Creolization in the Caribbean. Matatu, n. 27-28 (2003), p. xxi.

60 Knörr, Towards Conceptualizing Creolization, p. 6.
} 
A legislação colonial no século XX estabeleceu uma discriminação entre os crioulos de Cabo Verde e os de São Tomé e Príncipe. Desde a primeira Constituição portuguesa de 1822 , todos os habitantes das colónias foram formalmente considerados cidadãos. Em 1926, o Estatuto Político, Civil e Criminal dos Indígenas (Decreto n. ${ }^{\circ}$ 12.533), aplicou o estatuto inferior de indígenas a angolanos e moçambicanos. Em 1927, o Decreto n. ${ }^{\circ} 13.698$ estendeu o estatuto aos guineenses, mas não se referiu aos cabo-verdianos nem aos são-tomenses. Muito mais tarde, em 1947, a Carta Orgânica do Império Colonial Português excluiu explicitamente os cabo-verdianos da classificação de indígenas. Essa disposição também incluiu o Estado da Índia e Macau, mas não São Tomé e Príncipe. ${ }^{61} \mathrm{Na}$ prática, porém, esse estatuto nunca foi aplicado aos são-tomenses, razão pela qual, em 1952, o Curador Geral dos Serviçais e Indígenas em São Tomé se queixou de que os autóctones "se apoderam de um direito que até hoje ainda lhes não foi concedido por diploma algum — o de cidadania". Ele defendeu o nivelamento perante a lei de todas as populações, ilhéus e serviçais africanos. Assim, tal nivelamento com o europeu seria apenas possível por meio do processo de assimilação. ${ }^{62}$ Também uma proposta de alteração à Lei Orgânica do Ultramar, da Câmara Corporativa, defendeu a indigenização dos são-tomenses. Entretanto, durante o debate da proposta na Assembleia Nacional, em janeiro de 1953, o deputado Ricardo Vaz Monteiro, antigo governador de São Tomé e Príncipe (1933-1941), recusou a inclusão do arquipélago no grupo das colónias de indigenato. Ele argumentou que "se à população nativa de $\mathrm{S}$. Tomé e Príncipe nunca se aplicou o regime de indigenato, não será agora necessário, e muito menos político, que depois de a população evoluída, e até cristanizada, a vamos submeter a esse regime" ${ }^{63}$ Foi a ameaça da aplicação do estatuto de indígenas aos são-tomenses que provocou, em fevereiro de 1953, uma situação que culminou no infame Massacre de Batepá, quando inúmeros forros indefesos perderam a vida. ${ }^{64}$ Foi na sequência desses acontecimentos sangrentos que, em junho daquele

Art. 246 da Lei Orgânica do Império Colonial Português, de 19 de abril de 1947.

Curador Geral dos Serviçais e Indigenas, São Tomé, 30/12/1952.

Diário das Sessões, n. ${ }^{\circ}$ 189, 17/01/1953, p. 491. V. Legislatura (1949-1953), $4^{\text {a }}$ sessão legislativa.

64 Sobre o Massacre de fevereiro de 1953, ver Gerhard Seibert, Camaradas, clientes e compadres: colonialismo, socialismo e democratização em São Tomé e Príncipe, Lisboa: Vega, 2001, pp. 76-93.

66 Afro-Ásia, 49 (2014), 41-70 
ano, a Lei Orgânica do Ultramar Português excluiu também São Tomé e Príncipe explicitamente do estatuto de indigenato, ${ }^{65} \mathrm{e}$, em 1961, por pressões internacionais, Portugal aboliu o regime de indigenato em todas as suas então colónias.

Os próprios são-tomenses reconhecem a sua história de mestiçagem biológica e cultural, mas afirmam-se como forros e africanos em vez de crioulos. Ilustrativo para essa afirmação é uma palestra de 2007 intitulada "Quem somos nós", do político e historiador amador são-tomense Albertino Bragança, que disserta sobre a questão da identidade nacional:

A resposta é imediata: somos santomenses, africanos, fruto de um longo processo de caldeamento de culturas que se encontraram na decorrência de um processo de colonização que, tendo embora posto em confronto gentes e civilizações provenientes da Europa e da África, amalgamou as vivências de senhores e escravos e deu azo a um povo orgulhoso das suas raízes plurirraciais e multiculturais. ${ }^{66}$

No século XIX, a recolonização de São Tomé e Príncipe somada às pressões de assimilação da cultura portuguesa sobre a elite local pelo regime colonial resultaram num certo desprezo da própria língua crioula pela sociedade e elite forras. Como consequência, depois da independência, em 1975, o forro perdeu terreno a favor do português, que se tornou a língua dominante e de maior prestígio no arquipélago, entendido por $99 \%$ da população (censo 2001), enquanto a lungwa santome é falada por apenas $72 \%$. No texto acima referido, Bragança lamenta que membros da elite são-tomense tenham vergonha quando, em determinadas circunstâncias, veem-se forçados a falar o crioulo local. ${ }^{67}$ Bem diferente é o estatuto do crioulo em Cabo Verde, pois até a Constituição define, no seu artigo 92, que "O Estado promove as condições para a oficialização da língua materna cabo-verdiana, em paridade com a língua portuguesa". Uma Comissão Nacional para a Língua Cabo-Verdiana, um órgão consultivo do governo, foi criada em $1989 .{ }^{68}$ A Constituição são-tomense

\footnotetext{
65 Castelo, O modo português de estar no mundo, p. 60

66 Albertino Bragança, “Quem somos nós”, São Tomé, 2007, texto fotocopiado.

67 Bragança, "Quem somos nós".

68 Veiga, "O Crioulo de Cabo Verde", p. 118.
} 
não contém nenhuma disposição de afirmação das línguas crioulas e muito menos existe comissão nacional similar em São Tomé e Príncipe, assim como não houve qualquer iniciativa cultural comparável com o movimento literário Claridade em Cabo Verde. ${ }^{69}$

As afirmações identitárias diferentes refletem-se também nos símbolos nacionais e nas notas bancárias dos dois países. Depois da independência, o PAIGC (PAICV desde 1981) valorizou as raízes africanas da sociedade e da cultura cabo-verdianas. Até 1992, Cabo Verde e Guiné-Bissau partilharam a bandeira nacional herdada do PAIGV, que se baseia nas cores pan-africanistas, e é formada por três faixas retangulares, sendo uma vermelha e vertical às outras duas, horizontalmente sobrepostas, de cores amarela e verde com uma estrela negra centrada na faixa vermelha. As notas de escudo em circulação tinham a efígie de Amílcar Cabral, o fundador do PAIGC, mas, depois da introdução do multipartidarismo e da vitória eleitoral da oposição em 1991, Cabo Verde não apenas escolheu uma bandeira diferente daquela da Guiné-Bissau, mas também voltou a referir-se às raízes europeias. A nova bandeira cabo-verdiana é azul, com dez estrelas representando as dez ilhas do arquipélago, uma clara referência simbólica à proximidade com a Europa e com os Estados Unidos. Desde 1999, as notas do escudo cabo-verdiano mostram o retrato do poeta branco Eugénio Tavares. Em contraste, depois das mudanças políticas de 1991, São Tomé e Príncipe manteve a sua bandeira de 1975 com as cores pan-africanistas. Desde a introdução, em 1977, da moeda são-tomense, a dobra, as notas sempre trouxeram a efígie do Rei Amador, o líder da grande revolta dos escravos de julho de 1595 em São Tomé. ${ }^{70}$

\footnotetext{
${ }^{69}$ Em 2009, a convite do então ministro de Educação, Jorge Bom Jesus, uma comissão constituída por dois linguistas estrangeiros e seis especialistas nacionais apresentou uma proposta de Alfabeto Unificado para a Escrita das Línguas Nativas de S. Tomé e Príncipe (ALUSTP). No ano seguinte, o mesmo ministro oficializou a proposta por um simples despacho ministerial. Apenas em agosto de 2012, o governo são-tomense aprovou o ALUSTP, contudo, apenas para um período experimental de cinco anos.

70 Em 23 de dezembro de 2008, o Banco Central de São Tomé e Príncipe (BCSTP) emitiu uma nota de 100.000 dobras com a efígie do poeta e geógrafo luso-são-tomense Francisco José Tenreiro (19211963), um mestiço. A nota traz a data de 3 de junho de 2005, porém foi posta em circulação só mais de três anos depois, devido à contestação política em torno do homenageado, visto que Tenreiro nunca defendeu a independência do arquipélago, mas foi deputado da Assembleia Nacional salazarista, de 1958 até à sua morte prematura.
} 


\section{Conclusão}

No século $\mathrm{XV}$, a expansão portuguesa criou as primeiras sociedades crioulas do mundo atlântico em Cabo Verde e São Tomé e Príncipe, dois arquipélagos desabitados naquela altura. A diferente posição geográfica e, interligada a esse fator, a diferença do clima e dos solos condicionaram a emergência de economias divergentes nos dois arquipélagos. Diferenças de salubridade e a distância da Europa e das rotas atlânticas resultaram em uma maior imigração europeia em Cabo Verde do que em São Tomé e Príncipe. Por sua vez, esses fatores levaram, em Cabo Verde, a uma redução da população escrava e a um maior grau da miscigenação da população. Depois da abolição da escravatura, em 1876, a sociedade crioula em Cabo Verde consolidou-se, enquanto, em São Tomé e Príncipe, uma segunda colonização e a consequente reemergência da economia de plantação impediram uma tal consolidação da sociedade. Em vez disso, o arquipélago tornou-se uma sociedade plural, constituída por três grupos principais: os colonos brancos, os forros e os contratados. A ausência de recursos naturais e a consolidação da sociedade cabo-verdiana facilitou a introdução do ensino que, junto com a emigração iniciada no século XIX, tornou-se um dos pilares da afirmação da sociedade crioula. No século XX, o factor "racial", a conotação de crioulo com mestiço ou mulato, levou, em Cabo Verde, à afirmação de uma identidade crioula e, em São Tomé e Príncipe, à afirmação de uma identidade africana. Nas duas sociedades crioulas, a perspetiva "emic" coincide com a perspetiva "etic", representada por António Correia e Mário Soares. Santomesidade é africanidade, cabo-verdianidade é crioulidade, também em termos "raciais".

Texto recebido em 05 de outubro de 2012 e aprovado em 15 fevereiro de 2013 


\title{
Resumo
}

Cabo Verde e São Tomé e Príncipe foram as primeiras sociedades crioulas do mundo atlântico. Inicialmente, em muitos aspetos, a colonização dos dois arquipélagos pelos portugueses era muito semelhante. Contudo, a diferente posição geográfica e as divergências do clima e do meio ambiente condicionaram o desenvolvimento de economias distintas e diferenças no grau da miscigenação nos dois arquipélagos. Diferente desenvolvimento socioeconómico no século XIX, marcado, em São Tomé e Príncipe, pela recolonização e pelo restabelecimento da economia de plantação e, em Cabo Verde, pela consolidação da sociedade crioula e pela emigração, reforçou as divergências existentes. As diferenças refletem-se em distintas afirmações identitárias das duas sociedades crioulas. Cabo Verde afirma uma singularidade da sua sociedade crioula, enquanto, em São Tomé e Príncipe, domina uma identidade africana.

Palavras-chave: crioulização - miscigenação - mundo atlântico - Cabo Verde - São Tomé e Príncipe

\begin{abstract}
Cape Verde and São Tomé and Principe were the first Creole societies in the Atlantic world. Initially, the colonization of the two archipelagos by the Portuguese was very similar in many aspects. However, the different geographic position with differences in climate and the natural environment conditioned the development of distinct economies and unequal degrees of miscegenation in the two archipelagos. Different socioeconomic developments in the nineteenth century, in São Tomé and Principe, marked by the re-colonization and the reestablishment of the plantation economy and, in Cape Verde, by the consolidation of the Creole society and by emigration, reinforced existing divergences. The differences are reflected in distinct identity statements in the two Creole societies. Cape Verde claims the singularity of its Creole society while, in São Tomé and Principe, an African identity dominates.
\end{abstract}

Keywords: Creolization - miscegenation - Atlantic world - Cape Verde - São Tomé and Príncipe

70 Afro-Ásia, 49 (2014), 41-70 